\title{
Selected Reference Books of 1959-1960
}

\author{
By CONSTANCE M. WINCHELL
}

\section{INTRODUCTION}

$\mathrm{L}$ IKE THE PRECEDING ARTICLES in this semiannual series ${ }^{1}$ this survey is based on notes written by members of the staff of the Columbia University libraries. Notes written by assistants are signed with initials. ${ }^{2}$

As the purpose of the list is to present a selection of recent scholarly and foreign works of interest to reference workers in university libraries, it does not pretend to be either well-balanced or comprehensive. Code numbers (such asA34, 1A26, 2S22) have been used to refer to titles in the Guide 3 and its Supplements.

\section{BiBliograPhY}

Bibliografija jugoslovenskih bibliografija, 1945-55 Beograd, Bibliografski Institut FNRJ, 1958. 270p.

Bibliographies on all subjects published in Yugoslavia between 1945 and 1955, either separately or as parts of articles or books, are recorded here in classified arrangement, with author and subject indexes. Similar to the series now appearing as part of the national bibliography in a number of countries, often in the form of annuals, this first postwar compilation for Yugoslavia may also be utilized as a key to the more serious studies and publications contributed by that country in all fields of knowledge. Entries are in Latin characters, with the indication "ciril" if the work cited is in the Cyrillic alphabet. Presumably a continuation is planned.-E.B.

Die Bibliographie in den europaischen Ländern der Volksdemokratie; Entwicklung und gegenwartiger Stand, von Todor Borov [et al.] Leipzig, VEB Verlag für Buch- und Bibliothekswesen, 1960. 165p. DM21.30. (Bibliothekswissenschaftliche Arbeiten aus der Sowjetunion und den Landern der Volksdemokratie in deutsche Úbersetzung. Reihe B, Band 3)

This work will be useful as a guide in a western language to bibliography in Albania, Bul-

1 CRL, January and July issues starting January 1952. 2 Reference: Eleanor Buist, Rita Keckeissen, Elizabeth J. Rumics, Eugene Sheehy, John Neal Waddell, Suzanne F. Wemple. Engineering: James D. Ramer.

a Constance M. Winchell, Guide to Reference Books (7th ed.; Chicago: ALA, 1951); Supplement (Chicago: ALA, 1954); Second Supplement (Chicago: ALA, 1956); Third Supplement (Chicago: ALA, 1960)
Miss Winchell is Reference Librarian, Columbia University Library.

garia, Poland, Rumania, Czechoslovakia, and Hungary. For each country an introductory essay by a native specialist reviews the major development of its bibliography up to 1944 . In a second section of each chapter there is a list of titles, with full entry, for the period after 1945, arranged under such headings as: bibliography of bibliography, general retrospective bibliography, current national bibliography and book selection lists; bibliography of periodicals and newspapers; indexes to periodical and newspaper articles, biographical dictonaries, and general encyclopedias. There is a selection of the more important subject bibliographies published since 1945. For the type of information which one might seek in Malcles (Supplement 1A101, 3A75) and perhaps up-date by means of UNESCO'S Bibliographical Services Throughout the World (Supplement 2429) this well-organized survey provides an additional approach for a complex area undergoing rapid change.-E.B.

Impex Reference Catalogue of Indian Books. New Delhi, Indian Book Export \& Import Co., [1960] 236p., 468p. Rs 40.

An in-print list of Indian books in the English language, arranged in two sections. Part I lists some 45 broad subjects with entries alphabetical by author within each subject; part II is an alphabetical listing of books entered by author, title, catchword title and sometimes by subject. Author entries in this section include reference to the subject classification used for the book in the first section. Subject headings do not conform to any standard list. Entries should include "author, title, sub-title, number of pages, price, year of publication, classification [used in Section 1], and publisher" (title page), but many are incomplete. Some government publications are listed in a separate section.-R.K.

New York. Public Library. Rare Book Division. Checklist of Additions to Evans' American Bibliography in the Rare Book Division of the New York Public Library. Compiled by Lewis M. Stark and Maud D. Cole. New York, New York Public Library, 1960. 110p. $\$ 3.50$. 
As the title indicates, this is "an attempt to bring together in one listing the record of "notin-Evans' titles" in the New York Public Library's Rare Book Division. Arrangement of the checklist is chronological, and the style of entry similar to that in volume 13 of Evans (Supplement 2A36). The 1289 items include numerous photostats and facsimiles, with location of the original indicated when known. A few revisions and corrections of Evans are noted, and references to standard imprint bibliographies are frequently provided. There is an index by item number.-E.S.

Tanghe, Raymond. Bibliography of Canadian Bibliographies. Toronto, Published in association with the Bibliographical Society of Canada by University of Toronto Press, 1960. 206p. $\$ 10$.

Added title page in French.

Limited to bibliographies of subjects "wholly or principally Canadian (person, event, place, etc.)," this volume is based on the McGill Library School's 1930 publication of the same title (Guide A190). Although bibliographies included in monographs or periodical articles are largely excluded, the work includes many unpublished dissertations, masters' essays, student compilations, and some items "in preparation." Bibliographical information is complete, with frequent explanatory notes in English or French according to the language of the work considered. Entries appear under 29 subject divisions; listing within each class is alphabetical by compiler. Bio-bibliographies are grouped in a single section, "Author bibliographies," regardless of field. Some initial confusion may result from the three separate indexes: one of compilers, a bilingual subject index, and an "author" index to the bio. bibliography section.-E.S.

\section{ENCYCLOPEDIAS}

Grand Larousse encyclopedique, en dix volumes. Paris, Librairie Larousse, [1960- ] v.1(In progress) $\$ 17.50$ per vol.

Contents: v.1, A-Bauernfeld.

A wide public should welcome this newest link in the long chain of Larousse encyclopedias (see Guide D27, D28, D29), not merely for its intrinsic merits, but because it is the first usable general French encyclopedia to appear in thirty years. (The Encyclopedie française, Guide D31, whatever its scholarly excellence, cannot, because of its arrangement, be considered an easily consulted reference source.)

The first of the ten projected volumes of the new work presents much that is admirable. Unmistakably a "Larousse" product in both content and arrangement, it, like its predecessors, is a dictionary as well as an encyclopedia; articles tend to be brief and entries very specific, so that there are often fifteen, twenty, or more entries on a single page. Although many of the articles are based on those in one of the older sets, many others are entirely new or largely rewritten, easily justifying the publisher's claim that it is a new work. According to the prefatory text there is increased attention to contemporary affairs, especially in scientific and technical matters. Bibliographies, consisting primarily of French works, seem well up-to-date, although they are inconveniently located not after the relevant articles but grouped together under subjects in a separate section at the end of each volume. Paper and illustrations are well above Larousse standards, although margins are so narrow that rebinding will be difficult. Inevitably, as new materials are added, others have been withdrawn, so that the custodian of a large reference collection will retain the earlier sets while gratefully receiving the new.-J.N.W.

Uj magyar lexikon [Az akademiai kiadó lexikonszerkesztosege] Budapest, Akadémiai kiadó [1959- ] v.l- (In progress)

Contents: v.1-2, A-F.

This is the first Hungarian encyclopedia published under the communist regime. Its avowed aim of providing a Marxist-Leninist interpretation is evident both in the selection of facts and in their interpretation. Intended for the general public, the brief, dictionary-type articles are unsigned, and only the longer ones have bibliographies; maps and illustrations are included. Although it will not replace the older, standard work, Revai nagy lexikon (Guide D45), it will be particularly useful for identification of Eastern European figures since it contains biographical sketches of both living and deceased persons.S.F.W.

\section{Book Reviews}

An Index to Book Reviews in the Humanities, v.1, no.l [Mar. 31, 1960- ]. Detroit 6, Mich. (P. O. Box 606), Phillip Thomson, 1960Quarterly. $\$ 7.50$ per yr., $\$ 8$ outside U.S.A.

The first issue of this welcome new tool lists reviews of approximately thirty-five hundred titles from nearly three hundred periodicals. "Humanities" is used to include almost all categories of adult books except scientific and technical, and the periodicals list is correspondingly broad, including the popular, the scholarly, and the specialized. Foreign language journals are not indexed, but foreign language books reviewed in English language periodicals, (e.g., Books Abroad and other journals devoted to foreign literatures) are included. Individual list- 
ings are brief and probably apt to confuse the novice. Periodical titles are represented by numbers, so that reference must then be made to the master list. Reviewers' names are given, but inclusive pagination is not, nor is there any other indication of the length of a review. Nevertheless, the enterprise appears to be a worthy one, and it is hoped that sufficient financial support will assure its continuance.-J.N.W.

\section{Dissertations}

Altick, Richard Daniel, and Matthews, William R. Guide to Doctoral Dissertations in Victorian Literature, 1886-1958. Urbana, Univ. of Illinois Press, 1960. 119p. $\$ 2.25$.

Stucki, Curtis W. American Doctoral Dissertations on Asia, 1933-1958; Including Appendix of Master's Theses at Cornell University. Ithaca, N. Y., Southeast Asia Program, Dept. of Far Eastern Studies, Cornell Univ., 1959. 131p. (Cornell Univ. Dept. of Far Eastern Studies. Southeast Asia Program. Data paper no. 37) $\$ 2$.

Lists of dissertations in specific subject fields make welcome additions to the reference collection. Of the two lists here considered, the Altick Guide deals with the more clearly defined subject and is somewhat more comprehensive, covering a longer period and being international in scope. It compares favorably with the Woodress list for American literature (Supplement 3R40) and is arranged on similar lines, though it does not include works in progress.

The Stucki volume lists only American dissertations, but attempts to cover the whole range of doctoral studies on Asia in the fields of the social sciences and humanities. Arrangement is by country, then by subject, with an author index. An appendix lists Cornell master's theses on Asia for the 1933-58 period-E.S.

\section{DIRECTORY}

Directory of University Research Bureaus and Institutes. 1st ed. Detroit, Mich., Gale Research Company, [1960] 199p. \$20.

This list includes college and university sponsored research organizations of the United States and Canada which have been "set up on a permanent basis, carrying on a continuing research program and formally identified by a specific or distinctive title." (Introd.) The entries are arranged by broad subject fields and, within each section, alphabetically by sponsoring institution.

Information includes the sponsoring institution, the name, address, and foundation date of the institute, name of the director and the number of permanent staff members. A short description of activities follows and, for some, principal serial publications and special conferences sponsored. There is an index arranged by sponsoring university and another arranged geographically by state and city.-R.K.

\section{Foundations}

New York. Foundation Library Center. The Foundation Directory, Ed. 1, Ann D. Watson and F. Emerson Andrews, Editors. Marianna O. Lewis, Assistant Editor. New York, Published for the Center by Russell Sage Foundation, 1960.817 p. $\$ 10$.

The Foundation Library Center has utilized the records of the Russell Sage Foundation as well as extensive files purchased from the American Foundation Information Service, publisher of American Foundations and their Fields, VII (1955) (Supplement 2L9), in the compilation of this new directory which lists 5502 nongovernmental, nonprofit foundations. Organized in the same manner as the earlier work, the arrangement is alphabetical under states, except for New York City which has a special section. In most cases, information given is for 1958 and includes name, address, date of establishment, donor, purpose and activities, financial data, officers, and trustees. There are indexes by subject fields, persons, and names of foundations.

A lengthy introduction defines the types of foundations treated and discusses their assets and expenditures, geographical distribution, fields of activity, etc. The advent of this useful directory is most welcome and it is hoped that it will be revised regularly and often.

\section{Social Science}

Eldridge, Hope Tisdale. The Materials of Demography: a Selected and Annotated Bibliography. Published by the International Union for the Scientific Study of Population and Population Association of America. [New York, Columbia University Press] 1959. 222p.

This volume supplements The University Teaching of Social Sciences: Demography ... edited by David V. Glass ([Paris] Unesco, 1957).

Compiled with the needs of the teacher of demography in mind, this selective listing of recent significant English-language materials for population analysis includes some four hundred books and articles, well annotated. A section on general works, which also lists useful serial publications in the field, is followed by eight more specific sections, e.g. "problems and methods of demographic analysis;" "statistical compendia." In large part the titles were culled from the Population Index's quarterly bibliographies. Cutoff date was 1958. Comparable bibliographies of demographic literature in French, Italian, and Spanish respectively are planned.-E.J.R. 


\section{ECONOMICS}

Kish, George. Economic Atlas of the Soviet Union. Ann Arbor, University of Michigan Press, 1960. 96p. maps. $\$ 10$.

In this atlas the U.S.S.R. is divided into fifteen regions, with four maps for each region: A, agriculture and land use; $B$, mining and minerals; $C$, industry; D, transportation and cities. Maps of the country as a whole show vegetation, major administrative divisions, air transportation, and population distribution. There is one page of text for each region, a bibliography of Russian sources, and an index to the 60 regional maps. The typography is excellent, and added clarity is achieved by limiting the amount of information on each map.-E.B.

\section{DICTIONARY}

Academia española, Madrid. Diccionario historico de la lengua espanola. Seminario de lexicografia: Director, Julio Casares; Subdirector, Rafael Lapesa Melgar; Redactor Jefe, Salvador Fernandez Ramirez. Madrid, 1960- . (In progress) 225 pesetas per fasc.

Contents: Fasc.l, A-abolengo.

The preface states that this dictionary will differ in many aspects from the one of the same title (Guide M430) which the Academy began to publish in 1933, but never finished. Compiled on the historical method, the meanings of each word are traced from the earliest times to the present. Whenever possible, each meaning is illustrated by fifteen quotations: five from sources earlier than 1500; five from works written 1500 to 1700; and five from works published after 1700. The quotations are from both Spanish and Latin American authors. Variants in orthography are given, often with references to other dictionaries. When completed, this will be a monumental work, useful not only as an historical dictionary of the Spanish language, but for the identification of quotations as well.-S.F.W.

\section{Abbreviations}

Plamenatz, Ilija P. Yougoslav Abbreviations; a Selective List. Washington, Slavic and Central European Division, Reference Dept., Library of Congress, 1959. 185p. $\$ 1$.

Abbreviations, with expansions and English translations of the names "of government institutions and official bodies, industrial and trade establishments, and the more important newspapers and periodicals" (Introd.). Cyrillic characters are transliterated, and official designations appear in the three official languages, SerboCroatian, Slovenian, and Macedonian. This is a welcome addition to two previous reference aids published under Library of Congress auspices: Czech and Slovak Abbreviations (Supplement 3M22) and Polish Abbreviations (Supplement 3M92).-E.B.

\section{SCIENCE}

McGraw-Hill Encyclopedia of Science and Technology. New York, McGraw-Hill, 1960. I5v. $\$ 175$.

Statistics are impressive for this fifteen volume encyclopedia: 9300 pages, 9336 illustrations, 7224 articles alphabetically arranged, and a 100,000 entry index in the last volume. Five Nobel Prize winners are among the 2015 authorities who are identified in the "Key to Names of Contributors," v.15, p. 1-14.

Articles are written at the level of the intelligent layman, not the specialist in the field. An introductory article generally provides a broad survey of each branch of science and technology, and separate articles cover the main subdivisions and more specific aspects. Cross references guide the reader to related topics.

Biographical and historical articles are ordinarily excluded, as are all but the pre-professional aspects of the behavioral and medical sciences. Bibliographies follow most of the longer articles and appear up-to-date and well chosen. Typography and format are excellent.

A yearbook, beginning in 1962, and "continuous revision" are planned to keep the information current.-J.D.R.

\section{Music}

Lawless, Ray McKinley. Folksingers and Folksongs in America. New York, Duell, Sloan and Pearce [1960] 662p. $\$ 10$.

This is a kind of omnibus volume on the collecting and singing of folksongs and ballads in the United States and parts of Canada. The main sections of the work present biographical sketches of singers of ballads and folksongs, an annotated bibliography of collections of these songs (including information on archives and bibliographical sources), and checklists of folksong titles and discography. In addition, there is a chapter on folk-music instruments and one on folklore societies and folk festivals. Convenient arrangement of materials within the sections, bibliographical footnotes, and indexes of names, subjects, and titles combine to make this a useful and easy-to-use reference book.-E.S.

\section{LiTERATURE}

Dizionario universale della letteratura contemporanea. [Milano] Mondadori [c1959- ] v.l. (In progress) il. $\$ 88$.

COLLEGE AND RESEARCH LIBRARIES 
Contents: v.1-2, A-K.

These are the first volumes of a new encyclopedia of world literature written by Italian scholars under the general editorship of Alberto Mondadori. To be in four volumes, the Dizionario is to contain some 6000 entries covering 1870 to 1960. The arrangement is alphabetical and items include authors, literary movements, important periodicals, prizes, national literatures, etc. Not only literary men, but some artists, scientists, sociologists, and political figures are included for their literary works with the purpose of integrating literature and social movements in a single panorama of modern civilization. Articles range in length from a paragraph to several pages; bibliographies include works by and about an author. Photographs of authors, events and places discussed, and colored reproductions of works of art serve as illustrations. Analytic indices and chronological tables are to appear in volume four-R.K.

Goethe-Bibliographie 1912-1950, hrsg. von Herbert Jacob. [Goedeke, Karl. Grundriss zur Geschichte der deutschen Dichtung aus den Quellen. 3.Auflage: Band IV/5. Berlin, Akademie Verlag, 1957-1960.] 997p.

Continues the register of Goethe studies to 1911 which appeared in Goedeke, Grundriss, 3. Aufl. Band IV/3 (Dresden, 1912) (R505). Continued by the annual Goethe bibliography in Goethe; vierteljahresschrift der Goethe-Gesellschaft.

Awe-inspiring in its comprehensiveness, this international classified listing of monographic and serial publications about Goethe includes such a range of topics as editions of Goethe's works, translations, dramatizations, parodies, musical settings, illustrations, and critical studies (with reference to reviews); studies about Goethe, his family, his times, his writings, his influence; comparative studies (e.g., Werther and Emilia Galotti, Mann's Doktor Faustus, Iphigenie in Euripides, Racine, Goethe); a chronological listing of Goethe celebrations, etc. Organization of the sections is excellent; the detailed table of contents and the index (triple column, p. 881997) make location of specific sub-topics or individual items easy. Essential for Goethe studies, this can also be of real value in research in less obvious fields such as modern German literature and comparative literature.-E.J.R.

Jahresbericht für deutsche Sprache und Literatur, bearb. unter Leitung von Gerhard Marx. Berlin, Akademie-Verlag, 1960- Bd. 1-

(Deutsche Akademie der Wissenschaften zu Berlin. Institut für deutsche Sprache und Literature). 979p $\$ 16.80$. Bd. 1, Bibliographie, 1940-1945.

For the use of scholars and librarians there have been available for many years two excellent annual surveys of current scholarship in Germanic language and literature, the Jahresbericht über die Erscheinungen auf dem Gebiete der germanischen Philologie and the Jahresbericht über die wissenschaftlichen Erscheinungen auf dem Gebiete der neueren deutschen Literatur. (For earlier changes in title, records of years covered and years of publication, see Guide R491, Supplement 2R74 for the former and Guide R509, R510, Supplement 3R74 for the latter). For various good reasons explained in a lengthy preface, the two lists have now been combined, and the present title constitutes the first volume of the new series. It is essentially a comprehensive bibliography of scholarly works on Germanic language and literature of all periods. Books, periodical articles, dissertations, and, helpfully, parts of books are all included, with the major European languages, except Slavic, represented. The two principal sections, language and literature, are logically divided by periods, which are further divided under appropriate sub-headings, including listings for individual authors. A briefer third section lists works on Friesian and Dutch subjects. There are separate, detailed author and subject indexes and a third index of words which are the subjects of linguistic treatment.J.N.W.

Klapp, Otto. Bibliographie der französischen Literaturwissenschaft. Bd. 1, 1956-1958. Frankfurt am Main, 1960. 428p. DM58.

Although this new current bibliograpny, to be a companion to Eppelsheimer (Supplement 3R72) is published in Germany with a German title, it has also a French title page and the work itself is in French. Interpreting French literature in a broad sense, the intention is to list books, articles, and these published during the period covered, dealing with various aspects as well as with individual authors. After an initial chapter of "Genéralites," the arrangement is by century from "Le Moyen Age" to the "Vingtième Siecle," with indexes by name and by subject.

In this volume some 400 periodicals, primarily from Europe and North America, and more than 100 miscellaneous collections have been analyzed. Spot checking with the French VII Biblography (Supplement 3R92) naturally shows some duplication although there would seem to be articles in each not found in the other, but, because of different arrangement and because French VII does not include a list of periodicals indexed, it is difficult to make a satisfactory comparison. It would seem probable that this new Bibliographie has more comprehensive coverage, particularly from European countries, but that both will continue to be useful. Bd. II, 1959-1960, is announced for spring 1961. 
Molinaro, J. A., Parker, J. H., and Rugg, Evelyn. A Bibliography of "Comedias Sueltas" in the University of Toronto Library. Toronto, University of Toronto Press, 1959. 149p. $\$ 3.50$.

"The Spanish suelta, approximately 15 by 20 centimetres in size, was published as a separate and integral unit during the eighteenth century and has now all but disappeared from circulation." (Preface).

This bibliography lists the sueltas in a special collection presented to the University and includes principally 18 th century editions of over 700 Spanish plays, from 1703-1825. The arrangement is alphabetical by title with indexes by author, and by publishers and booksellers.

Vulpius, Wolfgang. Schiller Bibliographie 1893. 1958. Weimar, Arion, 1959. 568p. (Weimar. Nationale Forschungs- und Gedenskstatten klassischen Literatur. Bibliographien, Kataloge und Bestandsverzeichnisse.) $\$ 8.00$.

This well-organized bibliography, an outgrowth of the Schiller celebration in 1955, is an impressive international selection of works by and about the German author. Some 1800 citations for Schiller's works (indicating editions, translations, text editions, etc.) are followed by more than 5500 listings for books, parts of books, newspaper and magazine articles, and some dissertations, ranging in subject from Schiller himself and aspects of his work to the cultural background of his time, Schiller societies, etc. Naturally the emphasis is on continental scholarship; a particular effort was made to list East European and Slavic materials, and some Oriental items are also included. Marginal headings, annotations, cross-references, and an author index add to the ease with which the bibliography can be used.-E.J.R.

\section{BIOGRAPHY}

Bol'shaia Sovetskaia Entsiklopediia. Biograficheskii slovar' deiatelei estestvoznaniia i tekhniki. Otv. red. A. A. Zvorykin. Moskva, 1958. 2v. ports.

As is acknowledged in the introduction, the publishing of biographical dictionaries in Soviet Russia has lagged behind other types of reference material in recent years. The editors of the Soviet encyclopedia, in collaboration with the Institute for the History of Science and Technology of the Academy of Sciences of the USSR, have helped to remedy the situation with two volumes containing approximately forty-five hundred articles. The biographees are historical and contemporary persons, of all nationalities, prominent in scientific and technical fields including medicine and agriculture. The articles are based on those in the second edition of the BSE, with some revision and updating. There is a supplementary alphabet in v. 2, p. $427-442$ for additional changes. A final section reviews biographical reference material, Russian and foreign. The articles have short "by and about" bibliographies, usually longer than in the BSE.-E.B.

Leningrad. Publichnaia biblioteka. Russkie sovet skie pisateli-prozaiki; biobibliograficheskii ukazatel'. Leningrad, 1959- . v. 1- . 20r.

Contents: v.1, Avdeenko-Zhestov.

A group of bio-bibliographical reference books for Russian authors of the Soviet period commences with the first volume of a series on prose writers, living and dead. For each author there is a one or two page biographical note, followed by a substantial bibliography. The bibliography is intended to be comprehensive for the author's publications in literature, and literary and art criticism, and selective for any writing as popularizer of science, or as publicist. Movie scripts and dramatizations are included, as well as books, articles, and dissertations about the author. The selection of authors to be included in the series was made by the directors of the Union of Writers of the R.S.F.S.R., and the names of compilers, with the authors assigned to them, are also given. The first volume includes 51 writers whose names fall within the first seven letters of the Russian alphabet. According to the introduction similar works are in preparation for dramatists, poets, and authors of children's books.-E.B.

Sovetskie pisateli; avtobiografi $v$ dvukh tomakh. Moskva, Gos. izd-vo khudozhestvennoi lit-ry, 1959. $2 \mathrm{v}$. ports. $44 \mathrm{r} 35 \mathrm{k}$.

Using a somewhat unusual approach for a biographical dictionary or reference work the editors have compiled two volumes consisting of autobiographical sketches by 130 Soviet writers. The emphasis is on the "older" generation whose creative work began in the nineteen twenties or earlier. Living authors have contributed sketches for the collection. For those who have died, the editors have selected from ten to twenty pages of autobiographical material previously published, supplementing these in most cases with later information. There is no attempt at bibliography. The list of authors appears to differ considerably from the list selected for the first volume of the bio-bibliographical series.E. B.

Who's Who in Soviet Science and Technology, compiled by Ina Telberg. New York, Telberg Book Co., [1960] 119 1. $\$ 12.80$.

Selecting about 1,000 living Soviet scientists from the Biograficheskii slovar' deiatelei estestvoznaniia $i$ tekhniki (see above) the compiler has translated into English the basic information 
as to date of birth, education, major positions, and awards. Additional description of the scientists' work has been compressed to a sentence or two and in many cases bibliography is omitted. An average entry contains about ten typewritten lines of information. The mimeographed format of this example of the Telberg "experiment in small circulation translation" is serviceably bound and legible, although somewhat awkward in size. A companion volume of biography in the humanities and social sciences is in preparation. -E.B.

\section{GEOGRAPHY}

Harris, Chauncy Dennison and Fellmann, Jerome D., comps. International List of Geographical Serials. Chicago, University of Chicago, 1960. 194p. (Chicago. University. Dept. of Geography. Research paper 63) \$4.

"The fundamental purpose of this list is to provide a comprehensive inventory of all known geographical serials, both those currently being published and those no longer active." (Introd.) Arrangement of the 1637 entries is by country of origin, then alphabetically by serial title or other main entry. Titles in Oriental languages and non-Latin alphabets are provided in their original form in an introductory listing preceding the transliterated entries. Bibliographical information is complete, and addresses are given for current publications. Page references to Union List of Serials, New Serial Titles, and the British Union Catalogue of Periodicals are provided for locating files. The introduction appears in English, French, German, and Russian. There is an index of titles and cross-references.

Although referred to as a third edition, the present work actually represents a second change of title as well. It does not wholly supersede the compilers' "second edition" (A Union List of Geographical Serials, 1950), since the latter indicated locations in certain French libraries which are not noted in the new list.-E.S.

\section{HISTORY}

Blaudin de The, Bernard. Essai de bibliographie du Sahare français et des régions avoisinantes. [2. ed.] Paris, Arts et Métiers Graphiques, 1960. $258 \mathrm{p}$.

This classified bibliography of 9301 items, books and periodical articles, is divided into two main sections, (1) Les Territoires du sud de l'Algerie and (2) . . Bibliographie du Sahara français et des regions avoisinantes, followed by a combined author index. Both parts are revisions of earlier published bibliographies and list works of the 19th and 20th centuries (up to December 31,1958 ) with occasional publications of earlier dates, and while predominantly French in coverage, include some materials in other languages.

Blegen, Theodore C. and Nydahl, Theodore L. Minnesota History; a Guide to Reading and Study. Minneapolis, University of Minnesota Press [1960] 223p. $\$ 5$.

Based on Dean Blegen's study outline, Minnesota, Its History and Its People (1937), this new guide is intended particularly for the use of teachers, students, and study clubs. The twelve chapters covering the period from pre-pioneer days to the present are sub-divided, with each of the 42 sub-sections treating a specific phase of Minnesota's political, economic, social, cultural, or religious history. Each sub-division presents a topical analysis of historical events, followed by a series of questions and suggestions for study, and a list of references. Although the lists are not intended as exhaustive bibliographies, they include both books and periodical articles, and many entries are annotated. Lack of an index seriously impairs the usefulness of the volume. -E.S.

Carman, Harry J. and Thompson, Arthur W. $A$ Guide to the Principal Sources for American Civilization, 1800-1900, in the City of New York: Manuscripts. N.Y., Columbia University Press, 1960. 453p. $\$ 10$.

The first of two proposed volumes (the second is to treat printed materials), this useful handbook is designed to provide for the 19th century what the Greene and Morris Guide ... (Supple. ment 2V13) does for earlier periods. Basic arrangement of the resources described is topical, similar to the manuscripts section of Greene and Morris; details of scope and treatment are explained in the preface. A voluminous first section entitled "General and Political," chronologically subdivided, is followed by a number of subject chapters ranging alphabetically from "Architecture" to "Theatre." In each major section national materials are presented first, followed by listings by individual state. Within each division items are listed by date. Individual notations are concise, but clear and to the point, although it has been obviously impossible to provide any substantial analysis of specific items in many of the larger subject collections. A useful list of libraries and depositories, with summary descriptions of relevant holdings, precedes the text, and an index of some five thousand names follows it.-J.N.W.

Ellis, John Tracy. A Guide to American Catholic History. Milwaukee, Bruce Publishing Company [cl959] 147p. $\$ 2.50$.

A classified, annotated bibliography of some 800 items designed to serve as a guide to Ameri- 
can Catholicism. Chapters cover guides, manuscript depositories, general works, diocesan and parish studies, biographies, religious communities, education, special studies, periodicals, and historical societies. Books, articles, pamphlets, masters' and doctoral theses are included. Arrangement within a category is alphabetical by author. Introductory notes to each subdivision indicate the nature and limitations of the items listed and the strength and weakness of the literature in the particular field. Critical annotations make the work a valuable guide; a full author-title-subject index facilitates its use.-R.K.

Lamer, Hans [et al.] Dizionario della civilta classica. Traduzioni di Roberto Fertonani [et al.] [Milano] Il Saggiatore, [1959] 821p. il. (La Cultura. 5)

A translation, with minor revisions, of the author's Worterbuch der Antike, Leipzig, 1933. Articles cover such obvious categories as personal and place names, institutions, phrases, customs, art forms, etc. Most of them are brief and without bibliographies; more important topics, e.g., "Ateneo," "Grecia," "Latino," are generally longer and have brief bibliographies, mostly Italian. Format is attractive, and plates are nu. merous and handsome, although placed with little relevance to the accompanying text.J.N.W.

The Louisiana Union Catalog. Baton Rouge, Louisiana Library Association, 1960. 912p. $\$ 30$.

Originally issued in 1959 for distribution to the contributing Louisiana libraries, this catalog has been reprinted with a few corrections, but without additions. The Louisiana holdings of 60 libraries within that state are represented, with some out-of-state locations for items gleaned from the American Imprints Inventory of the Historical Records Survey. "In addition to ... books by Louisiana authors and books about Louisiana (adult and juvenile), the Union Catalog also contains ... sheet music, brochures, leaflets, programs, periodicals, unpublished theses, and maps." (Pref.) Format and page appearance are similar to that of the Library of Congress catalog. A card file at the Louisiana State Library will continue the catalog, and printed supplements at two-year intervals are proposed.-E.S.

Ramos, Roberto. Bibliografia de la revolucion mexicana. [2 ed.] Mexico, D.F. (Av. Dos No.
226, San Pedro de los Pinos, México 18), the Author, 1959-60. 3v. \$5.25.

Contrary to the implication contained in a sales letter from the author, this is not entirely a new edition, as the first two volumes, containing 3,130 entries, are merely new printings of the originals of 1931 and 1935 (Guide V378). Volume three is considerably expanded, listing nearly 2000 items published since 1935 . Volume contents are by period of publication; arrangement within each is alphabetical by main entry, usually with quite full bibliographic information. There are some brief annotations and a rudimentary subject index for each volume. With such an impressive amount of material, it seems unfortunate that the entire work was not re-edited, with items arranged in one alphabet and with a really useful subject index.-J.N.W.

U. S. Library of Congress. General Reference and Bibliography Division. A Guide to the Study of the United States; Representative Books Reflecting the Development of American Life and Thought. Prepared under the direction of Roy P. Basler . . Washington [U. S. Govt. Print. Off.] 1960. 1193p. \$7.

The Guide is intended as "an introduction to representative books that reflect the development of life and thought in the United States. In no sense is it a source of information about every conceivable facet of that life; nor has it any completeness as a catalog or compilation of Americana." (Introd.) Despite its necessary selectivity, the volume is somewhat staggering in aim and achievement. The 32 chapters include such headings as: literature; geography; general, diplomatic, military, intellectual, and local history; science and technology; education; religion; economic life; politics, etc., with numerous subdivisions for each. There are nearly 6500 numbered entries, most of which are annotated. Many annotations include citations and evaluative notes for related works not given numbered entries. The terminal date for some sections is 1955; others list items published through 1958. There is an index of authors, subjects, and titles.

An important reference tool in its own right, the Guide does not (nor is it intended to) replace the Harvard Guide or the bibliography of the Literary History of the U.S., but will serve as a supplement to both. It should prove particularly useful at institutions offering programs in American studies.-E.S. 